\title{
Methyl bromide alternatives evaluated for California strawberry nurseries
}

\author{
by Steven A. Fennimore, John M. Duniway, \\ Greg T. Browne, Frank N. Martin, \\ Husein A. Ajwa, Becky B. Westerdahl, \\ Rachael E. Goodhue, Milton Haar \\ and Christopher Winterbottom
}

The recent phase-out of the soil fumigant methyl bromide (MB) due to its impact on stratospheric ozone presents a huge challenge to strawberry nursery producers. We evaluated the effectiveness of alternative fumigants on soil pests and plant productivity, as well as production costs in California strawberry nurseries. Our trials followed nursery stock through lowand high-elevation phases of runnerplant propagation and a complete cycle of fruit production in coastal fields. Plant yields from the nurseries and fruit yields from Oxnard and Watsonville indicated that nursery plots treated with iodomethane plus chloropicrin, with 1,3-dichloropropene followed by dazomet, and with chloropicrin followed by dazomet produced runner-plant yields that were similar to methyl bromide plus chloropicrin. However, our economic analysis suggests that nursery profitability may nonetheless suffer from the loss of methyl bromide.

M ethyl bromide (MB) is a fumigant that is applied to the soil before planting to provide season-long control of soilborne pathogens, insects, nematodes and weeds. Several vegetable, fruit and perennial crops rely on methyl bromide for pest control (USDA ERS 2000). In the United States, tomatoes, strawberries and peppers account for most of the methyl bromide used in soil fumigation $(30 \%, 19 \%$ and $14 \%$, respectively) (Carpenter et al. 2000). Other crops that use methyl bromide include almonds,

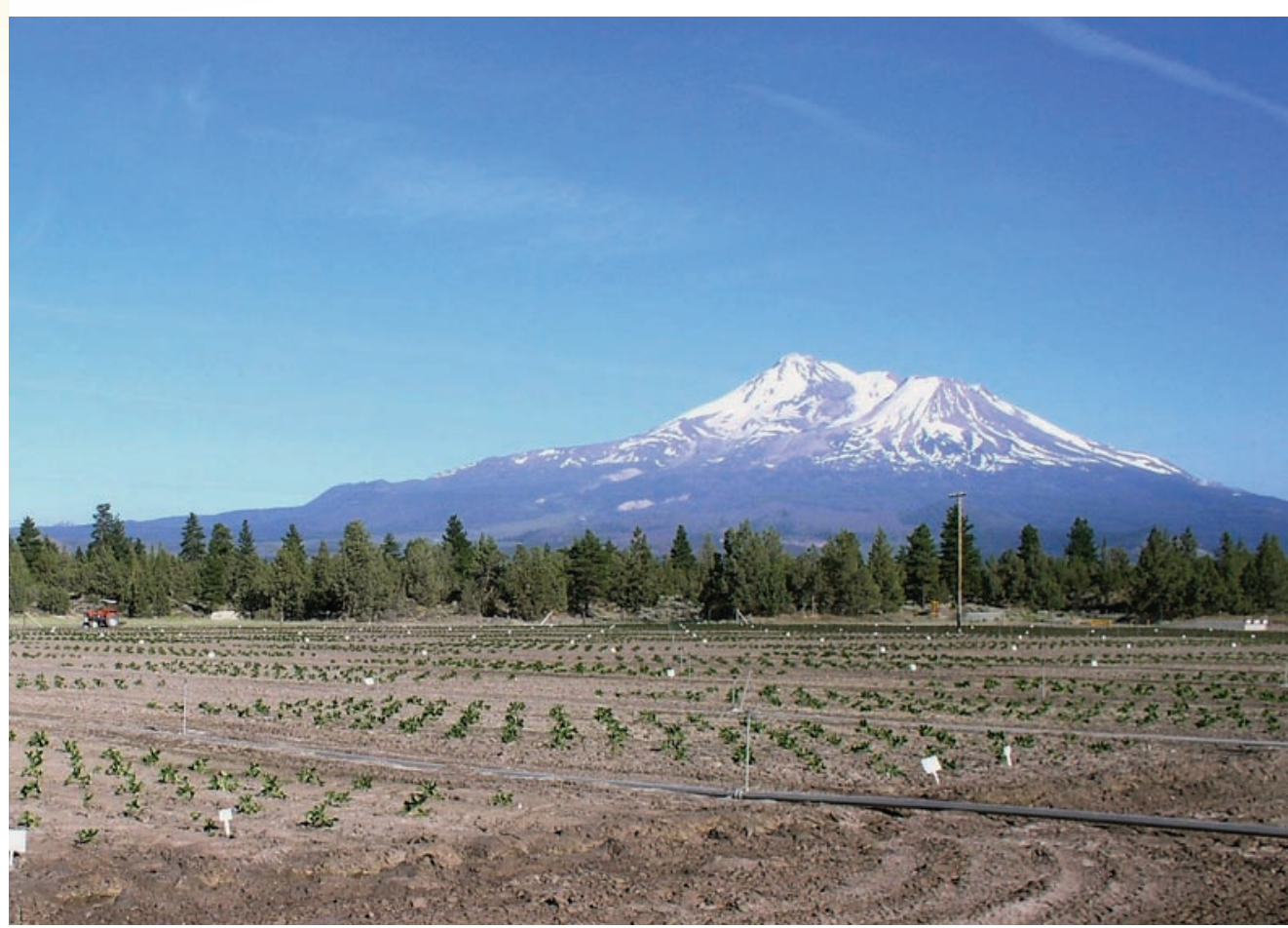

California strawberry runner plants are propagated in high-elevation nurseries such as this one near Macdoel, north of Mt. Shasta. The harvested runner plants are transported to fruiting fields in California or exported to other states or countries.

eggplants, grapes, melons, peaches, nectarines, plums, prunes, sweet potatoes, walnuts and ornamental as well as nursery crops. Of the 7.1 million pounds of methyl bromide used in California in 2004, strawberry producers applied 3.2 million pounds $(45 \%)$, primarily for soil fumigation (DPR 2006). The benefits of methyl bromide use are clear; for example, in one study strawberry yields were 94\% higher with methyl bromide fumigation than without fumigation (Shaw and Larson 1999).

However, methyl bromide that escapes into the atmosphere can reach the stratosphere, where it depletes ozone. An international treaty and domestic legislation completed a phase-out of methyl bromide in 2005, but the treaty allows for critical-use exemptions and quarantine for cases where no technically and economically feasible alternatives exist, or when significant market or regulatory disruptions would result without use of the fumigant. These exemptions are reviewed annually and are only considered where a critical need has been demonstrated (Martin 2003).
The economic consequences of the methyl bromide phase-out could be severe. Goodhue, Fennimore and Ajwa (2005) estimated that revenues for California strawberry growers would decline by roughly $25 \%$. Although the price of strawberries would increase, the reduction in the quantity sold would be large enough that revenues would decline. As the price of strawberries increases, consumers would purchase fewer strawberries. Consequently, consumer surplus, the difference between what consumers are willing to pay for strawberries and what they pay in the market, would decline by an estimated 50\%. Osteen and Caswell (1999) estimated that U.S. strawberry producers and consumers could lose $\$ 131.5$ million annually due to the methyl bromide phase-out.

\section{Alternative fumigants}

In the short term, growers will likely turn to other registered fumigants, which include: chloropicrin (trichloronitromethane), 1,3-dichloropropene (1,3-D), metam sodium (so- 
dium N-methyldithiocarbamate) and dazomet. Fumigants are often used in combination. Trade names for different formulations of 1,3-D plus chloropicrin are Telone C35 and InLine; for chloropicrin (CP) alone, Chlor-OPic, Metapicrin, Tri-Clor and others. Metam sodium, available as Vapam HL and Sectagon 42, and dazomet, available as Basamid, are broad-spectrum biocides that are effective on pathogens, nematodes and weeds. The new fumigant iodomethane (IM; Midas) now has a federal registration and is being considered for registration in California (US EPA 2007).

Nonchemical alternatives such as solarization have been tested (Hartz et al. 1993), but due to the cool and foggy conditions in most strawberry production areas, it is not likely to be an economically viable alternative to methyl bromide for most producers. Organic strawberry fruit production is still a small part of the industry, currently (in 2008) grown on about 1,600 of California's 35,700 acres in strawberries. Production of strawberries without use of fumigants is an active area of research for both organic and conventional systems.

The potential for 1,3-D use in California is limited due to the classification of this product as a possible human carcinogen. Its use is restricted to 90,250 pounds per 36 -square-mile township per year (Carpenter et al. 2001). Chloropicrin is regarded as more effective against fungal pathogens than methyl bromide and degrades rapidly in sunlight and soil into environmentally benign products (EXTOXNET 2001), but it is less effective on nematodes and weeds (Himelrick and Dozier 1991). Metam sodium is less expensive than most of the alternative fumigants and controls many weeds effectively (Goodhue et al. 2005), but it does not provide adequate control of Verticillium wilt, a major strawberry disease. Iodomethane is not yet registered in California.

\section{Information needs}

Time is growing short, and California strawberry fruit and nursery plant producers need to know if alternatives to methyl bromide are effective, how they should be applied and what

\section{Time is growing short, and California strawberry fruit and nursery plant producers need to know if alternatives to methyl bromide are effective.}

rates should be used. Producers also need to know if these fumigants are cost-effective. Regulators need information on fumigant emissions and worker safety to regulate the use of these potentially hazardous products. Nursery stock certification agencies, such as the California Department of Food and Agriculture, must determine whether alternative fumigants can be used to grow clean nursery stock (CDFA 2001). The public has health and environmental concerns. Available information on the efficacy and economics of the alternatives to methyl bromide does not meet these needs.

California strawberry nurseries annually produce approximately 1 billion vegetatively propagated transplants (runner plants) that are used in fruiting fields, $40 \%$ of which are shipped to other states and countries (CSC 1999).

Aside from the logical need for nurseries to provide pathogen-free plants for transplanting into commercial fruitproducing fields, the industry also must comply with rigorous phytosanitary and certification requirements to ensure that the transplants are pathogen- and nema- tode-free (CDFA 2001). For these reasons, the nursery industry relies heavily on preplant fumigation with methyl bromide and chloropicrin $(\mathrm{MB}+\mathrm{CP})$.

The production of strawberry runner plants is a multiyear and multilocation process that begins in virus-free rearing facilities such as screen houses. Plants are then vegetatively propagated in the field for two or three seasons. One or two 8-month-long propagation seasons at a low-elevation ( $<500$ feet) nursery are followed by a 5-month-long propagation at a high-elevation ( $>3,500$ feet) nursery. Favorable warm climatic conditions at the low-elevation nursery allow rapid plant propagation (Voth 1989). The high-elevation nursery is important to provide additional plant number increases and proper conditioning for fruit production in commercial fields (Voth and Bringhurst 1990).

University of California researchers Larson and Shaw (2000) evaluated alternative fumigant treatments in low- and high-elevation nurseries to measure the effects on runner-plant production. However, until we began this project, no comprehensive studies had been con-

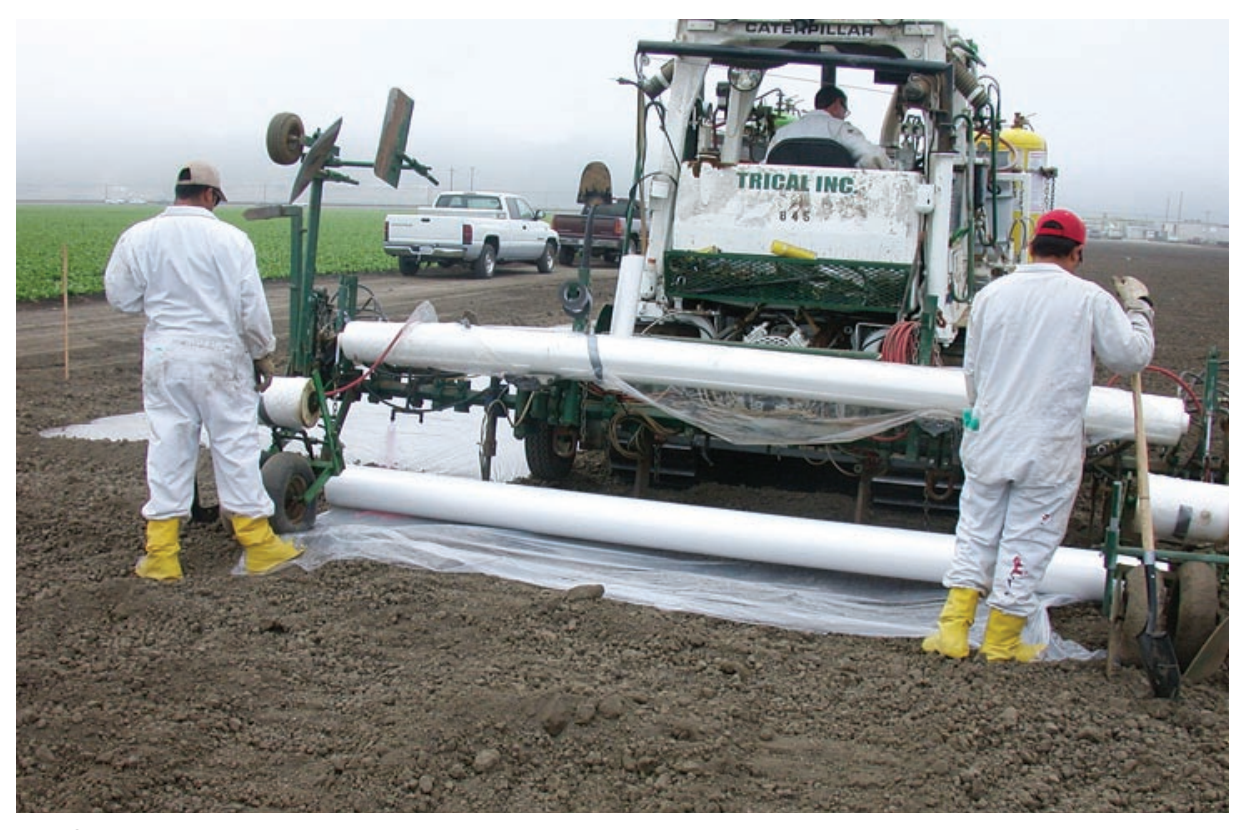

The fumigant methyl bromide - which is being phased out due to its impacts on the ozone layer - was used as a standard for the control of soilborne pests and diseases in all the nurseries and fruiting fields in this study. Above, methyl bromide is applied in a fruiting field near Watsonville. 


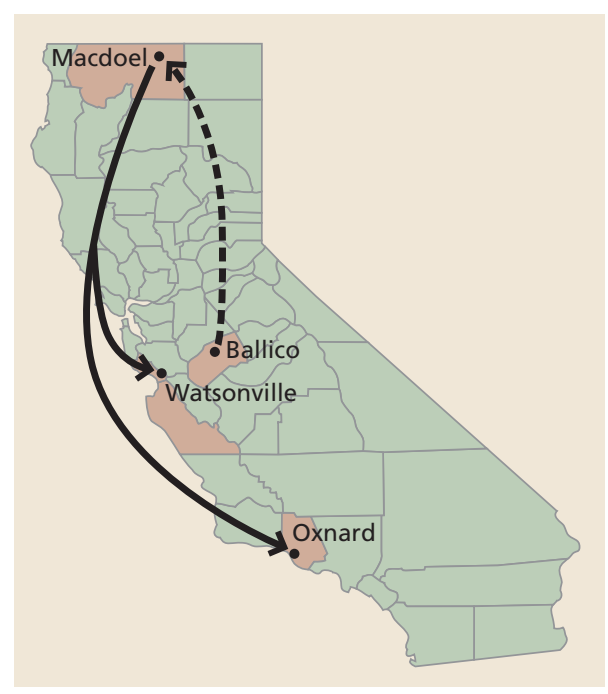

Fig. 1. Nursery production evaluations were conducted at a low-elevation site at Ballico. Harvested runner plants were then transported to Macdoel for use in the high-elevation experiment. Fruit evaluations were conducted on the coast at Watsonville and Oxnard.

ducted in strawberry nursery and fruit production systems to evaluate the effects of alternative fumigants on disease, nematode and weed control. We monitored the movement of plants through the system, allowing inferences to be made about the cumulative effects of fumigation. In addition, we gathered and evaluated information on the economics of production for each treatment. To our knowledge iodomethane has never before been evaluated in California strawberry nurseries. More detailed methods and results are published elsewhere (Kabir et al. 2005).

\section{Nursery and field research}

Treatments. Field evaluations of alternative fumigants were conducted in 2000 and 2001, in a low-elevation (390 feet) nursery at Ballico in Merced County and in a high-elevation $(4,200$ feet) nursery at Macdoel in Siskiyou County (fig. 1). Commercial-grade formulations of fumigants were used.

The treatments evaluated at Ballico were: (1) a mixture of iodomethane and chloropicrin $(50 \% \mathrm{IM}+50 \% \mathrm{CP})$ at 350 pounds per acre (lb/ac); (2) a mixture of methyl bromide and chloropicrin $(57 \% \mathrm{MB}+43 \% \mathrm{CP})$ at 400 pounds per acre; and (3) an untreated control.

At Macdoel, the treatments evaluated were: (1) equal amounts of iodomethane and chloropicrin at 350 pounds per acre; (2) methyl bromide plus chloropicrin at 400 pounds per acre $(57 \% \mathrm{MB}+43 \% \mathrm{CP})$; (3) chloropi-

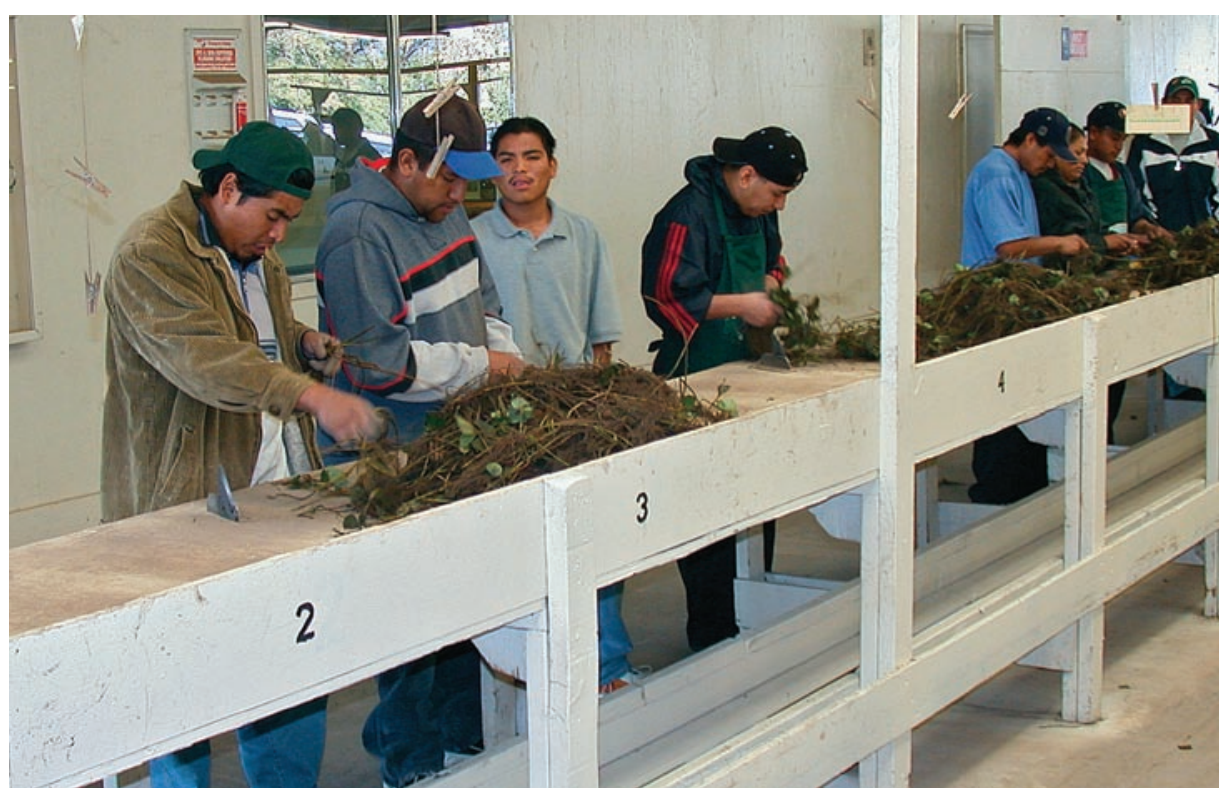

At Lassen Canyon's trim shed in Redding, workers sort strawberry plants harvested the previous day from high-elevation nursery fields. The workers separate healthy, marketable plants, trim them and then pack them for shipment to fruiting fields on the California coast. crin alone at 300 pounds per acre followed by (fb) 250 pounds per acre of $(61 \% 1,3-\mathrm{D}+35 \% \mathrm{CP})$ at 392 gallons per acre followed by 250 pounds per acre of dazomet; and (5) an untreated control.

The fumigants were shank-injected and the soil was simultaneously covered with plastic film that was left in place for 7 days. The day after the film was removed at Macdoel, dazomet was applied to treatments 3 and 4 using a granular spreader and incorporated with sprinkler irrigation according to label directions. The strawberry variety 'Camarosa' was used in all studies, primarily because it accounted for approximately $40 \%$ of the California strawberry acreage when this study was conducted (Hokanson and Finn 2000) and is grown in both Oxnard and Watsonville fruit-production areas.

Strawberry plants produced at the Ballico low-elevation nursery were harvested and used to plant the highelevation experiment at Macdoel (fig. 1). Plants produced at the Macdoel nursery were harvested and used to plant plots dazomet (DZ); (4) 1,3-D plus chloropicrin located in commercial strawberry fields at Oxnard and Watsonville, where fruit production was evaluated. In the experimental design, plants from all three Ballico treatments were planted in all plots at Macdoel. Plants from all five treatments at Macdoel were planted at Oxnard and Watsonville in soils fumigated with chloropicrin, and with methyl bromide plus chloropicrin. Equal numbers of plants were established in each plot at the beginning of every experiment.

Careful tracking of the strawberry plants produced on soils treated with iodomethane plus chloropicrin or with methyl bromide plus chloropicrin, or untreated soils at Ballico, allowed us to measure whether plant productivity at the Macdoel high-elevation nursery was affected by Ballico low-elevation fumigant treatments (fumigant carryover effect). Similarly, the tracking of plants from the five Macdoel fumigation treatments to the fruiting fields in Oxnard and Watsonville allowed us to measure the effects of high-elevation nursery fumigation on fruit yield (table 1).

\begin{tabular}{llllll}
\multicolumn{7}{c}{ TABLE 1. Study parameters for strawberry growing periods } \\
\hline Location & Trial type* & Fumigation date & Plant source & Plant date & Harvest date \\
\hline Ballico & LEN & Apr. 25, 2000 & MB + CP stock & May 12, 2000 & Jan. 15, 2001 \\
Macdoel & HEN & Aug. 26, 2000 & Ballico trial 1 & April 20, 2001 & Oct. 2, 2001 \\
Watsonville & Fruit & Sept. 27, 2001 & Macdoel trial 2 & Oct. 26, 2001 & Mar. 19-Aug. 7, 2002 \\
Oxnard & Fruit & Aug. 17, 2001 & Macdoel trial 2 & Oct. 8, 2001 & Feb. 5-June 24, 2002 \\
\hline *LEN = low-elevation nursery, HEN = high-elevation nursery; both produce runner plants. &
\end{tabular}


Efficacy evaluation. Fumigant efficacy was evaluated by burying pathogen and nematode samples before fumigation, retrieving the samples after fumigation, and determining the viable percentage. Sachets containing inoculum of Phytophthora cactorum (causes Phytophthora crown rot), Pythium ultimum (part of a pathogen complex that causes black root rot), Verticillium dahliae (causes Verticillium wilt) and citrus nematode (Tylenchulus semipenetrans) were buried 6, 12, 24 and 36 inches deep at two locations in each plot (only the 12- and 36-inch data are discussed here; they are representative of the shallow and deep samples, respectively).

Weed control. Two methods were used to assess weed control: (1) prior to each hand-weeding event, weed densities were measured in two or four randomly selected, 0.25-square-meter samples per plot; and (2) the effect of treatments on hand-weeding was determined by measuring the time required for an experienced fieldworker to hand-weed one row 150 feet long. The cooperating growers determined when cultivation or hand-weeding would be conducted. Season-long totals for weed density were used for statistical analysis.

Data analysis. Means and standard errors for the pathogen-sample survival data were determined using an Excel spreadsheet. Weed control, runnerplant production and fruit yield data were subjected to analysis of variance using SAS statistical software, and mean separation was performed using Duncan's multiple range test at the 5\% level of significance.

\section{Soil pathogen control}

Citrus nematode. Citrus nematodes in the sachets were killed by iodomethane plus chloropicrin, and methyl bromide plus chloropicrin, at Ballico (data not shown). At Macdoel, 1,3-D plus chloropicrin followed by dazomet controlled citrus nematode, and a small number of nematodes survived the treatments with iodomethane plus chloropicrin and with methyl bromide plus chloropicrin, but chloropicrin followed by dazomet did not control nematodes (fig. 2).
P. cactorum. P. cactorum in the sachets was killed by iodomethane plus chloropicrin at 350 pounds per acre to a depth of 36 inches at both nurseries. The methyl bromide-plus-chloropicrin standard controlled P. cactorum to 24 inches at Ballico (not shown) and 36 inches at Macdoel. Chloropicrin followed by dazomet controlled the pathogen to 12 inches and 1,3-D plus chloropicrin followed by dazomet controlled $P$. cactorum down to 36 inches.

P. ultimum. All of the fumigant treatments controlled P. ultimum at both nursery locations.

V. dahliae. Iodomethane plus chloropicrin controlled $V$. dahliae to 12 inches at Ballico and Macdoel, with 2\% or less survival at 24 and 36 inches at both locations. Methyl bromide plus chloropicrin controlled $V$. dahliae to 12 inches at Ballico and 36 inches at Macdoel. Chloropicrin followed by dazomet controlled $V$. dahliae to 12 inches, but 1,3-D plus chloropicrin followed by dazomet did not control this pathogen fully at any depth.

Soil samples. In addition to the pathogen sample bags installed in the plots, bulk soil samples were taken before and after fumigation at Ballico and Macdoel to measure control of pathogens in the field soil. Prefumigation populations of $P$. cactorum were low at both sites, but P. ultimum was more abundant. All but the iodomethaneplus-chloropicrin treatment completely controlled P. ultimum populations in Macdoel (IM + CP had 7\% survival). All fumigation treatments at Macdoel, except 1,3-D plus chloropicrin, fully controlled $V$. dahliae present in bulk soil at depths of 0 to 8 inches; 1,3-D plus chloropicrin reduced survival by approximately 85\% (Duniway, unpublished).

\section{Weed control}

Common weeds at the Ballico lowelevation nursery were carpetweed (Mollugo verticillata) and prostrate spurge (Euphorbia humistrata). The iodomethane-plus-chloropicrin and methyl bromide-plus-chloropicrin treatments reduced densities of these weeds compared to the untreated control, and weed densities did not differ significantly between these two treatments (table 2). All fumigants tested at the Macdoel high-elevation nursery reduced hairy nightshade (Solanum sarrachoides) and pigweed (Amaranthus spp.) densities compared to the untreated control, and none of the alternative fumigants differed from methyl bromide plus chloropicrin in effect.

Less time was required to handweed the plots treated with methyl bromide plus chloropicrin or iodomethane plus chloropicrin at the

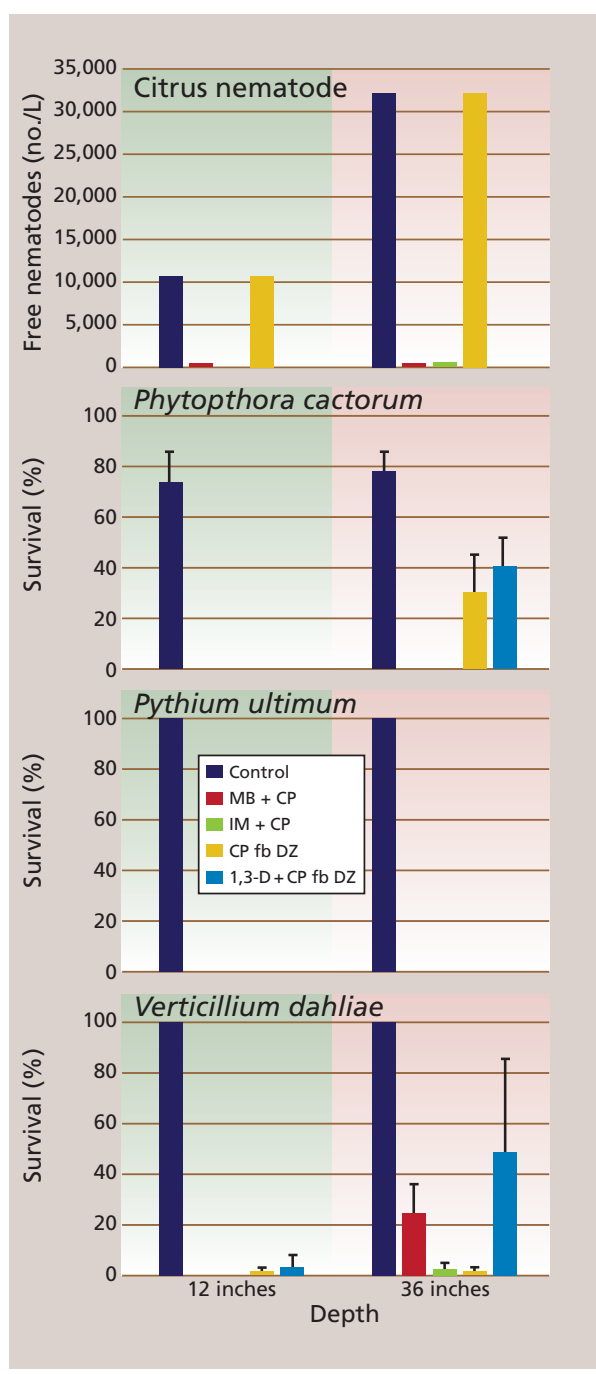

Fig. 2. Survival of citrus nematode (Tylenchulus semipenetrans), Phytophthora cactorum (causes Phytophthora crown rot), Pythium ultimum (part of a pathogen complex causing black root rot) and Verticillium dahliae (causes Verticillium wilt) buried at 12 and 36 inches at Macdoel in August 2000, with fumigation prior to the 2001 production season. Standard errors are plotted for all pathogens, and are shown. 
TABLE 2. Effect of alternative fumigants on season-long weed densities at Ballico low-elevation and Macdoel high-elevation nurseries

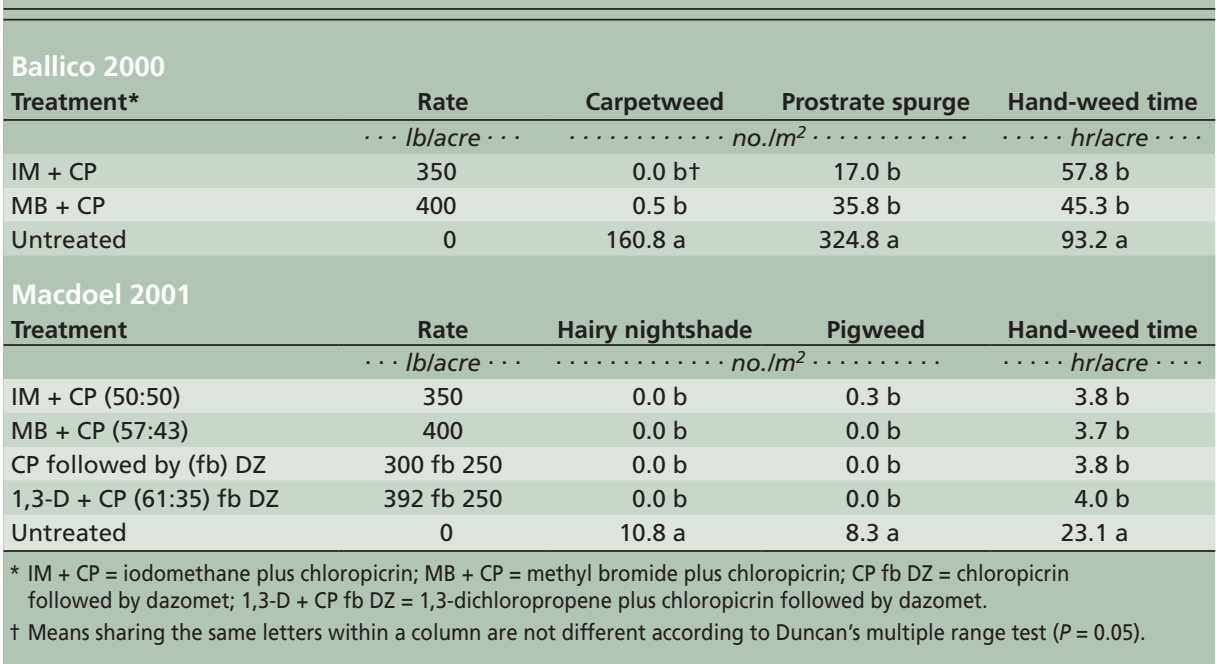

low-elevation nursery compared to untreated plots, and the weeding times between plots treated with methyl bromide plus chloropicrin and iodomethane plus chloropicrin did not differ significantly (table 2). At the high-elevation nursery, weeding times were similar for all fumigants, and all fumigated plots had lower weeding times than the untreated plots.

\section{Plant yield and economics}

Runner-plant yields per acre at the low-elevation nursery (Ballico) in plots treated before planting with iodomethane plus chloropicrin $(626,300$ plants) did not differ significantly from those treated with methyl bromide plus chloropicrin (705,300 plants), and both fumigation treatments yielded more plants than the untreated plots (292,700 plants). At the high-elevation nursery (Macdoel), all of the preplant fumigation treatments significantly increased plant production to similar levels (452,200 to 486,600 plants), which were greater than the numbers produced in the nonfumigated control soil (355,900 plants). No carryover effects from the low-elevation nursery were detected in plant yields at the high-elevation nursery. Similarly, Larson and Shaw (2000) found that the greatest effects of fumigants were on the "final runner propagation cycle" or high-elevation nursery, rather than carryover effects.

Methyl bromide plus chloropicrin had the highest net return per acre.
Treatment costs, hand-weeding costs and yields varied, while other costs and the price of plants were assumed to be identical across treatments. Net returns per acre were $\$ 9,906$ lower for the untreated control than for methyl bromide plus chloropicrin at Macdoel, which was a decline of $23.8 \%$. Net returns per acre for iodomethane plus chloropicrin were $\$ 942$ lower than those for methyl bromide plus chloropicrin, a reduction of $2.3 \%$. Net returns per acre for chloropicrin followed by dazomet were $\$ 944$ lower (2.3\%), and net returns for 1,3-D plus chloropicrin followed by dazomet methyl bromide plus chloropicrin.

For the fumigation treatments, these differences were relatively small in percentage terms, due largely to differences in treatment costs. If the relative price of methyl bromide plus chloropicrin became higher or the cost of the other treatments went down, then the differences in net returns per acre would be smaller. If the price of methyl bromide plus chloropicrin increased by $50 \%$, then the average net returns per acre for iodomethane plus chloropicrin, and chloropicrin followed by dazomet, would be virtually identical to the methyl bromide-pluswere $\$ 2,539$ lower (6.1\%) than those for chloropicrin net returns per acre.

Because all of the fumigation treatments had weeding times that were significantly lower than those for the untreated plot but not significantly different from each other, and because all of the fumigation treatments had yields that were significantly higher than those of the untreated plot but not significantly different from each other, differences in net returns per acre were driven largely by differences in treatment costs.

\section{Fruit production evaluation}

Plants harvested on Oct. 2, 2001, at the high-elevation Macdoel nursery were transplanted to commercial fruit production fields near Oxnard and Watsonville about 1 week after harvest. To determine whether nursery treatment influenced responses to fruiting field treatments, half of the plots at Oxnard and Watsonville were fumigated with chloropicrin and the other half with methyl bromide plus chloropicrin (Kabir et al. 2005). At both sites, fruit yields were higher in the soils fumigated with methyl bromide plus chloropicrin than with chloropicrin alone (table 3).

Fumigants used at the Macdoel nursery did not affect fruit yields at Oxnard or Watsonville, with one exception: plants at Macdoel on soil previously fumigated with chloropicrin followed by dazomet and transplanted 
into soils fumigated with methyl bromide plus chloropicrin at Watsonville yielded significantly more marketable fruit than plants grown on methyl bromide plus chloropicrin at both the Macdoel nursery and Watsonville fruiting field (table 3). The failure to detect a loss in fruit yield on the plants produced on untreated soils at Macdoel may be due to the fact that the high-elevation nursery's field was relatively clear of soilborne pathogens, and runner plants of conventional commercial quality were selected for transplanting (Kabir et al. 2005).

\section{Methyl bromide replacements}

Based on these production and pest management evaluations, the alternative fumigants evaluated here are all potential replacements for methyl bromide in runner-plant nurseries. However, the economic analysis suggests that methyl bromide plus chloropicrin is still most cost-effective (although the differences were small in percentage terms) and that nursery plant producers could be at an economic disadvantage when the methyl bromide phase-out is fully implemented. The international competitiveness of strawberry nursery production may also change based on whether producers in other countries can continue to produce strawberry plants with methyl bromide.

The relative economic performance of the alternative treatments will depend on the relative cost of methyl bromide compared to the price of the alternative fumigants. The sequential application of chloropicrin $(300 \mathrm{lb} / \mathrm{ac}$ ) or 1,3-D plus chloropicrin (392 lb/ac) for pathogen control, followed by dazomet (250 lb/ac) for weed control, in the nurseries resulted in runner-plant production equivalent to the standard methyl bromide-plus-chloropicrin treatment. The mixture of iodomethane plus chloropicrin resulted in plant yields in the low- and high-elevation nurseries that were similar to methyl bromide plus chloropicrin.

However, iodomethane is not yet registered as a soil fumigant in California, and further research is needed to optimize the iodomethaneplus-chloropicrin mixture and rates for the management of specific soilborne pests. Treatment with iodomethane plus chloropicrin, chloropicrin followed by dazomet, and 1,3-D plus chloropicrin followed by dazomet all provided runner plants of sufficient quality and vigor to support fruit yields in commercial production fields similar to the standard nursery fumigation treatment, methyl bromide plus chloropicrin.

Fruit yields from nursery stock produced on soils previously fumigated with chloropicrin followed by dazomet were comparable to methyl bromide plus chloropicrin. At the high-elevation nursery, chloropicrin followed by dazomet was the more promising alternative treatment, and net returns were within $3.5 \%$ of methyl bromide plus chloropicrin. The lower fruit yields of chloropicrin-only plants compared to methyl bromide-plus-chloropicrin plants at Oxnard and Watsonville suggest that chloropicrin alone at the rates used is not an acceptable substitute for methyl bromide in fruit production fields (Kabir et al. 2005).

\section{S.A. Fennimore is Associate Extension Special-} ist, Department of Plant Sciences, UC Davis; J.M. Duniway is Professor Emeritus, Department of Plant Pathology, UC Davis; G.T. Browne is Research Plant Pathologist, U.S. Department of Agriculture (USDA), Davis, Calif.; F.N. Martin is Research Plant Pathologist, USDA, Salinas, Calif.; H.A. Ajwa is Associate Extension Specialist, Department of Plant Sciences, UC Davis; B.B. Westerdahl is Professor and Extension Specialist, Department of Nematology, UC Davis; R.E. Goodhue is Associate Professor, Department of Agriculture and Resource Economics, UC Davis; M. Haar is Assistant Professor, University of Minnesota, Lamberton; and C. Winterbottom is Agronomist, Sierra Cascade Nursery, Susanville, Calif.

The USDA-CSREES Methyl Bromide Transitions Program (00-51102-9535, 2002-51102-01929) provided financial support for this project. The California Strawberry Commission, Arysta Life Science Corporation, Lassen Canyon Nursery, Sierra Cascade Nursery, Coastal Berry, Martinez Berry and Sea Crest Farms provided material support. We thank Cecil Martinez, Stuart Yamamoto, Gary Williamson, Scott Scholer and Glenn Imoto for their patience and help. We thank Doug Dopkins and Luis Guerrero for technical and field assistance.

\section{References}

Carpenter J, Gianessi L, Lynch L. 2000. Economic impact of the scheduled U.S. phase-out of methyl bromide. National Center for Food and Agricultural Policy, Washington, DC. www.ncfap.org/reports/pesticides/ methyl\%20bromide/methylbromide.htm.

Carpenter J, Lynch L, Trout T. 2001. Township limits on 1,3-D will impact adjustments to methyl bromide phase-out. Cal Ag 55(3):12-8

[CDFA] California Department of Food and Agriculture. 2001. Summary of California Laws and Regulations Pertaining to Nursery Stock. Sacramento, CA www.cdfa.ca.gov/phpps/PE/Nursery/pdfs/nipm_11_ insp_movmt_of_trees.pdf.

[CSC] California Strawberry Commission. 1999. Crop profile of strawberries in California. National Pesticide Assessment Program. Davis, CA. http://pestdata. ncsu.edu/cropprofiles/docs/castrawberries.html.

[DPR] California Department of Pesticide Regulation. 2006. Summary of pesticide use report data 2005: Indexed by chemical. Sacramento, CA. www. cdpr.ca.gov/docs/pur/pur04rep/comrpt04.pdf (accessed Oct. 5, 2007).

EXTOXNET. 2001. Extension Toxicology Network. Pesticide information profile - chloropicrin. http:// extoxnet.orst.edu/pips/chloropi.htm (accessed Oct. 6, 2007).

Goodhue RE, Fennimore SA, Ajwa HA. 2005. The economic importance of methyl bromide: Does the California strawberry industry qualify for a critical use exemption from the methyl bromide ban? Rev Ag Econ 27:198-211

Hartz TK, DeVay JE, Elmore CL. 1993. Solarization is an effective soil disinfestation technique for strawberry production. HortScience 28:104-6.

Himelrick DG, Dozier WA Jr. 1991. Soil fumigation and soil solarization in strawberry production. Adv Straw Prod 10:12-28.

Hokanson SC, Finn CF. 2000. Strawberry cultivar use in North America. HortTechnol 10:94-106.

Kabir Z, Fennimore SA, Duniway JM, et al. 2005. Alternatives to methyl bromide for strawberry runner plant production. HortScience 40:1709-15.

Larson KD, Shaw DV. 2000. Soil fumigation and runner plant production: A synthesis of four years of strawberry nursery field experiments. HortScience 35:642-6.

Martin FN. 2003. Development of alternative strategies for management of soilborne pathogens currently controlled with methyl bromide. Ann Rev Phytopathol 41:325-50.

Osteen C, Caswell M. 1999. Facing the phase-out of methyl bromide. USDA Economic Research Service. Ag Outlook A60-263. p 24-7.

Shaw DV, Larson KD. 1999. A meta-analysis of strawberry yield response to preplant soil fumigation with combinations of methyl bromide-chloropicrin and four alternative systems. HortScience 34(5):839-45.

[USDA ERS] US Department of Agriculture Economic Research Service. 2000. Economic implications of the methyl bromide phase-out. Ag Info Bull No 756

[US EPA] US Environmental Protection Agency. 2007. Time-limited registration of iodomethane (methyl iodide). www.epa.gov/pesticides/factsheets/ iodomethane_fs.htm\#content (accessed Oct. 5, 2007).

Voth V. 1989. The effect of nursery location latitude on California winter planted strawberries. Acta Hort 265:2883-4.

Voth V, Bringhurst RS. 1990. Culture and physiological manipulation of California strawberries. HortScience 25:889-92. 